\title{
MENAKAR KUALITAS PEMERIKSAAN PAJAK DALAM SENGKETA PAJAK
}

\author{
I Gede Komang Chahya Bayu Anta Kusuma \\ Politeknik Keuangan Negara STAN \\ Beny Setiawan \\ Politeknik Keuangan Negara STAN \\ David Yanuar Sugiharto \\ Direktorat Jenderal Pajak
}

Alamat Korespondsi : gedebayuanta@gmail.com

\section{INFORMASI ARTIKEL}

Diterima Pertama

30 Agustus 2019

Dinyatakan Diterima

23 September 2019

KATA KUNCI:

Pemeriksaan pajak; sengketa pajak; standar pemeriksaan; bukti pemeriksaan; kualitas hasil pemeriksaan.

KLASIFIKASI JEL:

$\mathrm{H} 2 \mathrm{O}$

\section{ABSTRACT}

In a self assessment system, Directorate General of Taxes has the authority to conduct audits of reported taxpayer's tax returns. Notice of Tax Assessment issued as a result of the inspection mostly causes a tax dispute and the legal remedies submitted are mostly granted by the Tax Court. This research looks at this issue. The focus is why tax disputes arise and how the quality of audit results so that audit findings can be maintained. For this purpose, this research uses a qualitative descriptive study aimed at describing, summarizing various conditions, situations, social reality phenomena that occur in the community in relation to tax audits and disputes. The research reveals that firstly, tax audit standard as a minimum achievement that must be achieved in tax audit. Tax audit standards have been implemented, tax audit findings need to be supported by audit evidence and the applicable tax rules. Secondly, taxpayers objection and appeal submit for make sure that the tax return contains information that reflects taxpayer's reality and the applicable tax rules. Third, audit quality results are audit findings that have been supported by audit evidence based on techniques and this audit evidence can be used as evidence in the Tax Court

\section{ABSTRAK}

Penerapan self assessment, DJP berwenang melakukan pemeriksaan atas SPT Wajib Pajak yang sudah dilaporkan. Surat ketetapan pajak yang diterbitkan hasil pemeriksaan terdapat sebagian sengketa pajak dan upaya hukum yang diajukan sebagian besar dikabulkan oleh Pengadilan Pajak. Tujuan penelitian ini, untuk mengetahui timbulnya sengketa pajak dan kualitas hasil pemeriksaan agar temuan pemeriksaan dapat dipertahankan. Penelitian ini, deskriftif kualitaif bertujuan menggambarkan, meringkas berbagai kondisi, situasi, fenomena realitas sosial yang terjadi di masyarakat dalam kaitannya dengan pemeriksaan dan sengketa pajak. Hasil penelitian menemukan, pertama standar pemeriksaan sebagai capaian minimum yang harus dicapai dalam pemeriksaan yaitu temuan pemeriksaan yang didukung bukti pemeriksaan dan dasar hukum yang berlaku. Kedua, Wajib Pajak mengajukan upaya hukum untuk kepastian hukum dan meyakini kewajiban perpajakan ditetapkan sesuai kenyataan dan peraturan pajak. Ketiga, Hasil pemeriksaan berkualitas apabila didukung bukti pemeriksaan berdasarkan hasil pengujian teknik pemeriksaan dan pengumpulan bukti secara kompeten yang cukup dan dapat digunakan sebagai alat bukti di Pengadilan Pajak. 


\section{PENDAHULUAN}

\subsection{Latar Belakang}

Tugas Direktorat Jenderal Pajak (DJP) adalah menghimpun penerimaan negara dari sektor pajak. Sebagai sumber penerimaan andalan, target penerimaan pajak setiap tahunnya terus mengalami peningkatan. Pada tahun 2018 realisasi penerimaan pajak mencapai Rp 1.315,9 triliyun atau 92,4 \% dari target yang ditetapkan oleh pemerintah. Kondisi ini tentunya memacu DJP untuk terus berupaya membuat terobosan untuk mencapai target 2019.

Mencapai target penerimaan bukan sesuai yang mudah, banyak sekali faktor yang mempengaruhi secara internal maupun eksternal dalam menghimpun penerimaan pajak. Sistem self assessment yang diterapkan di Indonesia tentunya mewajibkan setiap Wajib untuk menghitung, menyetor dan melaporkan kewajiban perpajakannya sesuai kondisi yang sebenarnya dan DJP sebagai otoritas perpajakan mempunyai tugas melayani, menyuluh, mengawasi dan melakukan pemeriksaan sebagai upaya penegakan hukum kepada Wajib Pajak apabila kewajiban perpajakan tidak dilaksanakan sesuai kondisi yang sebenarnya.

Penelitian yang dilakukan Gunarso menunjukkan bahwa pemeriksaan pajak dan sanksi perpajakan berpengaruh terhadap perilaku patuh Wajib Pajak. (Gunarso, 2016). Namun demikian, kepatuhan ini belum secara langsung berdampak kepada kenaikan penerimaan pajak, karena sebagian besar surat ketetapan pajak sebagai hasil pemeriksaan diajukan upaya hukum keberatan dan banding oleh Wajib pajak. Data mengenai hasil keputusan banding yang diterbitkan oleh Direktorat Keberatan dan Banding dan data Pengadilan Pajak terlihat pada tabel. 1.1.

Tabel 1.1. Tingkat Kemenangan Banding DJP di Pengadilan Pajak

\begin{tabular}{|l|c|c|c|c|}
\hline \multicolumn{1}{|c|}{ DJP } & $\mathbf{2 0 1 5}$ & $\mathbf{2 0 1 6}$ & $\mathbf{2 0 1 7}$ & $\mathbf{2 0 1 8}$ \\
\hline Menang & $32,54 \%$ & $36,44 \%$ & $40,07 \%$ & $40,15 \%$ \\
\hline Kalah & $67,46 \%$ & $63,56 \%$ & $59,93 \%$ & $59,85 \%$ \\
\hline
\end{tabular}

Berdasarkan data di atas, terlihat persentase kemenangan DJP lebih kecil dari Wajib Pajak. Kondisi ini menimbulkan pertanyaan mengapa hasil pemeriksaan tidak dapat dipertahankan sehingga putusan pengadilan pajak lebih banyak mengabulkan permohonan Wajib Pajak. Salah satu pegawai Penelaah Keberatan menjelaskan bahwa dikabulkannya permohonan Wajib Pajak disebabkan temuan pemeriksaan disanggah Wajib Pajak dan kondisi ini diakibatkan karena kualitas pemeriksaan masih lemah. Kondisi ini tentunya harus segera ditelusuri penyebabnya, karena pemeriksaan pajak yang dilakukan kepada Wajib Pajak bertujuan untuk menegakkan hukum dan apabila hasilnya bertolak belakang maka pemeriksaan pajak yang dapat memberi efek jera tidak terwujud.

Beberapa penelitian yang terkait dengan pemeriksaan pajak telah dilakukan antara lain penelitian oleh Elim dan Panga (2015), menunjukkan pemeriksan pajak tidak efektif dalam meningkatkan penerimaan pajak. Penelitian ini difokuskan pada jumlah penerbitan Surat Perintan Pemeriksaan (SP2) dengan jumlah surat ketetapan pajak yang diterbitkan ternyata tidak mampu mencapai target penerimaan. Penelitian yang fokus terhadap kualitas pemeriksaan yang dilakukan Sunhaji (2013) menunjukan kompetensi dan etika pemeriksa pajak mempengaruhi kualitas proses pemeriksaan dan kualitas hasil pemeriksaan.

Hasil penelitian Hidayat dan Charoline (2013) menunjukan kualitas pemeriksaan terhadap peningkatan pencairan tunggakan pajak. Apabila pemeriksaan dilakukan secara baik dan benar maka berpengaruh kepada pencairan tunggakan pajak. Penelitian-penelitian sebelumnya sebagian besar fokusnya pada dampak dari dilakukannya pemeriksaan pajak terhadap kepatuhan dan peningkatan penerimaan pajak melalui pelunasan surat ketetapan pajak, dan pada penelitian kali ini, fokus pembahasan pada kualitas hasil pemeriksaan karena sangat menarik untuk dibahas. Disamping itu perlu juga ditelusuri mengapa hasil pemeriksaan yang dilakukan sesuai standar pemeriksaan dapat dimenangkan oleh Wajib Pajak? Apakah hal ini terjadi karena kualitas hasil pemeriksaan yang tidak bagus atau pembuktian yang tidak cukup untuk mendukung mendukung hasil pemeriksaan.

\section{LANDASAN TEORI DAN PENELITIAN SEBELUMNYA}

\subsection{Konsep Pemeriksaan Pajak}

Pemeriksaan pajak merupakan proses pengumpulan dan pengevaluasian bahan bukti yang dilakukan oleh orang yang kompeten. Pemeriksaan pajak cenderung kepada audit ketaatan (compliance audit), karena salah satu tujuan dari pemeriksaan pajak adalah untuk menguji kepatuhan pemenuhan kewajiban perpajakan (Kurniawan, 2011).

Untuk menguji kepatuhan wajib pajak dalam memenuhi kewajiban perpajakannya, maka Direktur Jenderal Pajak dapat melakukan pemeriksaan terhadap Wajib Pajak. Dari pelaksanaan pemeriksaan tersebut diharapkan adanya peningkatan kepatuhan tidak hanya dari Wajib Pajak yang diperiksa, melainkan dapat meluas yaitu dari Wajib Pajak lainnya (deterrent effect) maupun masyarakat yang belum terdaftar sebagai Wajib Pajak (Gunadi, 2004). Direktorat Jenderal Pajak (DJP) telah menetapkan peraturan tentang standar pemeriksaan yang digunakan untuk mengukur kualitas pemeriksaan yaitu capaian minimum yang harus dicapai dalam melaksanakan pemeriksaan. 


\subsection{Standar Pemeriksaan Pajak}

Berdasarkan pasal 1 angka 25 UU KUP, Pengertian pemeriksaan adalah rangkaian kegiatan untuk menghimpun dan mengolah data, keterangan dan/atau bukti yang dilaksanakan secara obyektif dan profesional berdasarkan suatu standar pemeriksaan untuk menguji kepatuhan pemenuhan kewajiban perpajakan dan/atau untuk tujuan lain dalam rangka melaksanakan ketentuan peraturan perpajakan. Dalam upaya menjaga mutu hasil pemeriksaan dan mengimplementasikan standar pemeriksaan yang telah diatur pada Peraturan Menteri Keuangan dan diturunkan juga dengan Peraturan Direktur Jenderal Pajak sehingga diharapkan dapat memberikan petunjuk pelaksanaan serta capaian minimum yang harus dicapai oleh pemeriksa pajak dalam melaksanakan tugas pemeriksaan. Dengan demikian melalui standar pemeriksaan ini sudah diatur keseragaman, ketertiban dan mekanisme pertanggungjawaban dari pemeriksa pajak dalam melaksanakan tugas pemeriksaan sehingga diharapkan proses pemeriksaan dapat berjalan secara efektif dan efisien serta dapat dipertangung jawabkan. Dalam standar pemeriksaan telah diatur secara rinci bagaimana pelaksanaan pemeriksaan harus memenuhi tiga standar utama yaitu standar umum, standar pelaksanaan dan standar pelaporan.

Pertama, standar umum pemeriksaan pada prinsipnya mengatur persyaratan umum seorang pemeriksa pajak antara lain telah mendapat pendidikan dan pelatihan teknis yang cukup sehingga mempunyai keterampilan sebagai Pemeriksa Pajak. Standar pelaksanaan pemeriksaan merupakan ketentuan yang mengatur secara rinci mengenai setiap tahapan proses pemeriksaan dan kelengkapan administrasi yang harus dipenuhi seorang pemeriksa mulai dari kegiatan pada tahap persiapan diantaranya membuat audit plan dan audit program. Kedua bagaimana pelaksanaan pemeriksaan mulai dari pemberitahuan pemeriksaan, peminjaman dokumen dan pengujian pos-pos SPT dengan menerapkan pilihan metode dan teknik pemeriksaan yang sesuai dengan pos SPT yang dilakukan pemeriksaan. Dalam standar ini juga diatur kapan proses pemeriksaan dapat dilakukan serta bagaimana pemeriksa pajak menghimpun bukti pemeriksaan atau alat bukti yang dapat digunakan sebagai dasar perhitungan pajak serta mendokumentasikannya dalam format baku berupa Kerta Kerja Pemeriksaan (KKP).

Ketiga, Standar pelaporan yang harus disusun dengan ringkas dan jelas memuat ruang lingkup, pos-pos yang diperiksa serta temuan hasil pemeriksaan, merupakan standar terakhir yang menjadi dasar menerbitkan produk hukum berupa surat ketetapan pajak, sehingga apabila hasil pemeriksaan yang telah dilakukan pemeriksa pajak tidak dituangkan dalam laporan pemeriksaan maka tidak akan terbit surat ketetapan pajak.

\subsection{Tahapan Pemeriksaan}

Proses pemeriksaan pajak merupakan serangkaian kegiatan yang dijabarkan dalam tiga tahapan yaitu mulai dari persiapan, pelaksanaan dan pelaporan. Pertama, tahap Persiapan pemeriksaan adalah serangkaian kegiatan yang dilakukan pemeriksa pajak sebelum memulai pemeriksaan. Persiapan ini dilakukan dalam rangka mencapai mencapai tujuan pemeriksaan secara efisien dan efektif. Persiapan yang wajib dilakukan berupa menyusun audit plan dan audit program serta sarana dan prasarana yang diperlukan selama pelaksanaan pemeriksaan. Pada audit plan ini Pemeriksa Pajak menentukan ruang lingkup pemeriksaan serta menentukan pos-pos SPT yang menjadi fokus pemeriksaan. Apabila fokus pemeriksaan telah ditetapkan melalui analisis yang tepat maka diharapkan pemeriksa pajak dapat menemukan kecurangan atau temuan dengan benar. Kedua Tahap Pelaksanaan Pemeriksaan, merupakan inti dari proses pemeriksaan. Kegiatan pada tahap ini meliputi seluruh proses kegiatan pemeriksaan mulai dari pemanggilan Wajib Pajak untuk hadir dalam rangka pemeriksaan pajak, meminjam buku catatan dan dokumen, pengujian pos-pos SPT, penyampaian Surat Pemberitahuan Hasil pemeriksaan (SPHP), pembahasan akhir hasil pemeriksaan sampai dengan ditandatanganinya Berita Acara Pembahasan Akhir Hasil Pemeriksaan (BAPAHP). Dalam pembahasan akhir ini merupakan tahap yang sangat menentukan bagaimana temuan pemeriksaan dibahas dan menelusuri seluruh data, keterangan dan bukti yang menjadi dasar temuan. Tahap terakhir yaitu penyusunan Laporan Hasil Pemeriksaan (LHP) yang nantinya menjadi dasar penyusunan Nota Penghitungan. Dalam Nota penghitungan sudah dituangkan jumlah perhitungan pajak menurut SPT dan perhitungan pajak menurut pemeriksa dan jumlah yang disetujui oleh Wajib Pajak. Selanjutnya Nota penghitungan diproses untuk diterbitkan surat ketetapan pajak.

\subsection{Bukti pemeriksaan dan alat bukti}

Dalam standar pemeriksaan dijelaskan bahwa bukti pemeriksaan yang digunakan sebagai dasar temuan harus bukti kompeten yang cukup. Bukti kompeten apabila bukti tersebut valid dan relevan dengan mempertimbangkan prinsip kewajaran dan kelaziman usaha apabila transaksi yang dilakukan oleh Wajib Pajak dengan pihak yang mempunyai hubungan istimewa. Bukti dinyatakan valid apabila bukti tersebut dapat diandalkan untuk pengambilan kesimpulan dengan mempertimbangkan tingkat validitasnya yaitu indepedensi dan kualitas sumber dimana bukti diperoleh, kondisi dan cara bukti diperoleh. Selanjutnya bukti harus relevan artinya bukti berkaitan dengan pos-pos yang diperiksa sesuai audit program yang sudah ditentukan. Terakhir bukti pemeriksaan juga harus cukup untuk mendukung 
temuan hasil pemeriksaan sesuai dengan pertimbangan profesional pemeriksa pajak. Jenis bukti pemeriksaan antara lain pemeriksan fisik, konfirmasi, dokumentasi, prosedur analitis, wawancara atau observasi sebagaimana diatur pada Surat Edaran Direktur Jenderal Pajak Nomor SE65/PJ/2013.

Menurut Gunadi (2016) Alat bukti adalah sesuatu yang ada hubungannya dengan suatu perbuatan yang dapat digunakan untuk bahan pembuktian agar menimbulkan keyakinan hakim atas suatu kebenaran adanya suatu tindak pidana yang dilakukan oleh terdakwa. Alat bukti ini juga berhubungan dengan pembuktian di pengadilan pajak apabila terdapat sengketa antara Wajib Pajak dengan DJP, alat bukti dapat berupa surat atau tulisan, keterangan ahli, keterangan para saksi, pengakuan para pihak,dan atau pengetahuan hakim. Contoh alat bukti antara lain akta pendirian, bukti setoran modal, buku jurnal, perjanjian, surat tagihan, buku rekening dll

\subsection{Sengketa Pajak}

Berdasarkan pasal 1 angka 5 UU Pengadilan Pajak sengketa pajak adalah sengketa yang timbul dalam bidang perpajakan antara wajib pajak atau penanggung pajak dengan pejabat yang berwenang sebagai akibat dikeluarkannya keputusan yang dapat diajukan banding atau gugatan kepada pengadilan pajak berdasarkan peraturan perundang-undangan perpajakan, termasuk gugatan atau pelaksanaan penagihan berdasarkan Undang-undang Penagihan Pajak dengan Surat Paksa.

Menurut Pohan (2014), apabila Wajib Pajak menilai bahwa perhitungan pajak yang dilakukan pada saat pemeriksaan ternyata tidak benar maka undang-undang KUP memberikan hak kepada Wajib Pajak untuk mengajukan upaya hukum berupa permohonan keberatan. Dan apabila wajib pajak merasa belum puas dengan keputusan keberatan tersebut maka Wajib Pajak dapat mengajukan permohonan banding kepada Pengadilan Pajak.

Dalam penelitian hukum yang dilakukan Asmorowati (2011) menjelaskan sengketa yang terjadi dalam bidang perpajakan disebabkan adanya ketidaksamaan persepsi/pemahaman terhadap ketentuan perpajakan atau perbedaan pendapat antara Wajib Pajak dengan Direktur Jenderal Pajak atas surat ketetapan pajak yang diterbitkan sebagai hasil pemeriksaan. Atas sengketa pajak ini dapat ditempuh upaya hukum berupa keberatan atas surat ketetapan pajak dan apabila belum cukup dapat dilanjutkan dengan mengajukan permohonan banding atas surat keputusan keberatan.

\subsection{Keberatan dan Banding}

Surat ketetapan pajak merupakan produk akhir dari proses pemeriksaan. Dalam rangka memenuhi azas keadilan, apabila dalam hasil pemeriksaan menurut Wajib Pajak masih terdapat perhitungan pajak yang tidak benar, maka dapat mengajukan keberatan dengan mekanisme sebagaimana diatur pada psal 25 UU KUP. Dalam permohonan keberatan ini, prinsip hukum pembuktian melekat pada Wajib Pajak sehingga Wajib Pajak harus menjelaskan ketidakbenaran surat ketetapan pajak dan menghitung jumlah pajak yang harus dibayar oleh Wajib pajak.

Dalam Jangka waktu 12 bulan sejak diterimanya surat keberatan, maka DJP sudah menerbitkan surat keputusan berupa diterima seluruhnya, diterima sebagian, ditolak dan menambah jumlah pajak. Banding adalah upaya hukum yang dilakukan Wajib Pajak atas suatu keputusan yang dapat diajukan banding, salah satunya keputusan keberatan. Permohonan banding diajukan apabila menurut Wajib Pajak dalam surat keputusan keberatan masih terdapat materi yang disengketakan dengan persyaratan yang diatur pada pasal 27 UU KUP.

Pada pasal 81 UU Pengadilan Pajak dinyatakan bahwa jangka waktu pengambilan putusan oleh pengadilan pajak dengan acara biasa dalam waktu 12 bulan sejak banding diterima. Putusan banding hampir sama dengan keputusan keberatan dapat berupa menolak pemohon banding, mengabulkan sebagian atau seluruhnya, menambah besarnya pajak yang harus dibayar, tidak menerima banding, membetulkan kesalahan tulis atau hitung atau membatalkan keputusan.

\subsection{Penelitian Sebelumnya}

Hasil penelitian yang berhubungan dengan pemeriksaan pajak sudah banyak diteliti khususnya mengenai dampak pemeriksaan terhadap kepatuhan. Hasil penelitian Elim dan Panga (2015), menunjukkan pemeriksan pajak tidak efektif dalam meningkatkan penerimaan pajak. Penelitian ini difokuskan pada jumlah penerbitan Surat Perintan Pemeriksaan (SP2) dengan jumlah surat ketetapan pajak yang diterbitkan ternyata tidak mampu mencapai target penerimaan. Penelitian yang fokus terhadap kualitas pemeriksaan yang dilakukan Sunhaji (2013) menunjukan kompetensi dan etika pemeriksa pajak mempengaruhi kualitas proses pemeriksaan dan kualitas hasil pemeriksaan.

Bwoga (2006) meneliti terhadap hasil pemeriksaan yang menunjukkan hasil pemeriksaan sebagai baian pengawasan yang dilakukan DJP akan selau menimbulkan sengketa karena adanya perbedaan prinsip yaitu mengacu PSAK dan DJP mengacu laporan keuangan fiskal. Hasil penelitian Hidayat dan Charoline (2013) menunjukan kualitas pemeriksaan terhadap peningkatan pencairan tunggakan pajak. Apabila pemeriksaan dilakukan secara baik dan benar maka berpengaruh kepada pencairan tunggakan pajak. Penelitian yang sama dilakukan juga dengan lokus berbeda oleh Nurlaila (2017) dan hasilnya adanya hubungan kualitas pemeriksaan terhadap peningkatan pencairan 
tunggakan pajak. Namun demikian dari penelitian sebelumnya, tidak ada penjelasan lebih lanjut mengenai bagaimana kualitas hasil pemeriksaan yang mampu dipertahankan di pengadilan pajak.

\subsection{Kerangka pemikiran}

Berdasarkan kondisi yang telah dijelaskan pada latar belakang dan landasan teori, pemeriksaan pajak merupakan salah satu cara DJP untuk menguji kepatuhan pelaksanaan kewajiban pajak dari Wajib Pajak sebagai konsekuensi diterapkannya sistem self assessment yang hasilnya diterbitkan surat ketetapan pajak. Terhadap surat ketetapan pajak yang sudah diterbitkan masih terdapat sengketa pajak dan Wajib Pajak mengajukan upaya hukum.

Surat keputusan atas upaya upaya hukum yang diajukan sebagian besar dimenangkan oleh Wajib Pajak, menjadi hal yang menarik untuk diteliti. Mengapa Wajib Pajak sebagian besar menyatakan menolak hasil pemeriksaan? Mengapa hasil pemeriksaan yang telah dilakukan sesuai standar pemeriksaan masih dapat dimenangkan oleh Wajib Pajak? Apakah hal ini muncul karena kualitas hasil pemeriksaan atau pembuktian yang tidak cukup untuk mendukung mendukung hasil pemeriksaan? Permasalahan ini yang menjadi pertanyaan yang ingin dijawab dalam penelitian ini yaitu bagaimana kualitas hasil pemeriksaan pajak sehingga wajib pajak dapat menang dalam upaya hukum khususnya pada tingkat banding di Pengadilan Pajak.

Secara umum kajian ini bertujuan untuk meningkatkan kesadaran pemeriksa pajak untuk meningkatkan kualitas pemeriksaan yang menjadi penyebab dikabullkannya upaya hukum yang dilakukan oleh Wajib Pajak. Dan akhirnya kajian ini diharapkan dapat menambah wawasan terkait kualitas pemeriksaan pajak yang perlu dijaga dengan harapan dapat memberikan deterrent effect kepada Wajib Pajak.

\section{METODE PENELITIAN}

Penelitian ini merupakan penelitian deskriftif kualitaif yang bertujuan untuk menggambarkan, meringkas berbagai kondisi, situasi, atau berbagai fenomena realitas sosial yang terjadi di masyarakat khususnya dalam melaksanakan pemeriksaan pajak (Burhan Bungin, 2011). Fenomena tersebut berupa tingginya jumlah kemenangan Wajib Pajak dalam upaya hukum banding di Pengadilan Pajak yang dilakukan atas hasil pemeeriksaan yang dilakukan oleh DJP

Menurut Burhan Bungin format penelitian deskriftif kualitatif lebih tepat apabila digunakan untuk meneliti masalah-masalah yang membutuhkan studi mendalam mengenai bagaimana kualitas pemeriksaan yang dihasilkan oleh DJP sehingga dapat dipertahankan di Pengadilan Pajak.

Sumber data dalam penelitian kualitatif ini berupa data primer yang diperoleh melalui wawancara mendalam kepada orang-orang yang dipandang tahu situasi sosial terkait penelitian dan penentuan sumber data dipilih secara purposive, yaitu dipilih dengan pertimbangan dan tujuan tertentu (Sugiyono 2014). Sumber data lainnya merupakan data sekunder yang diperoleh melalui studi literatur berupa buku, peraturan dan risalah putusan pengadilan yang terkait dengan penelitian.

Pengumpulan data dalam penelitian ini dilakukan dengan metode wawancara tidak terstruktur agar dapat mengetahui permasalahan secara mendalam dan data yang telah dikumpulkan dilakukan teknik triangulasi untuk menguji kredibilitas dari informasi yang diperoleh sehingga data menjadi lebih konsisten, tuntas dan pasti. Teknik triangulasi yang dilakukan pada penelitian ini adalah memadukan informasi yang dikumpulkan dari pihak yang diwawancara yaitu pejabat DJP, Pemeriksa Pajak, Dosen dan Wajib Pajak.

\section{HASIL PENELITIAN}

\subsection{Pemeriksaan Pajak}

Berdasarkan pasal 29 ayat 1 UU KUP memberikan kewenangan kepada Direktur Jenderal Pajak untuk melakukan pemeriksaan untuk menguji kepatuhan pemenuhan kewajiban perpajakan dari Wajib Pajak atau tujuan lain dalam rangka melaksanakan ketentuan perundang-undangan perpajakan. Pemeriksaan terhadap Wajib Pajak dilakukan berdasarkan kriteria pemeriksaan standar pemeriksaan yang sudah diatur pada Peraturan Meteri Keuangan Nomor : 17/PMK.03/2013 dan diturunkan juga dalam Peraturan Direktur Jenderal Pajak.

Penentuan kriteria Wajib Pajak yang diperiksa dan pelaksanaan standar pemeriksan saat ini menurut akademisi dan praktisi dianggap tidak jelas dan kurang obyektif karena Kriteria pemeriksaan dari tahun ke tahun semakin banyak, hal ini dirasakan tidak sejalan dengan tujuan pemeriksaan yaitu memberikan efek jera (deterrent effect) seharusnya dengan meningkatnya tingkat kepatuhan maka jumlah Wajib Pajak yang masuk target pemeriksaan akan semakin rendah. Mengenai penerapan standar pemeriksaan, menurut praktisi perpajakan menyatakan proses pemeriksaan harus lebih obyektif berdasarkan standar yang ditetapkan dengan berharap apabila proses pemeriksaan dilakukan sesuai standar akan dapat meningkatkan kepercayaan (trust) masyarakat untuk membayar pajak sesuai kondisi sebenarnya.

Menurut Widyaiswara yang sebelumnya juga pernah bertugas sebagai Pemeriksa Pajak menyatakan bahwa kriteria pemeriksaan saat ini sudah cukup dan yang perlu ditingkatkan adalah bagaimana pelaksanaan pemeriksaan ini dapat memberikan efek jera yaitu dengan mengimplementasikan teknik - teknik pemeriksaan secara benar sehingga surat ketetapan pajak yang diterbitkan mempunyai dasar pembuktian yang kuat dan sesuai kondisi yang sebenarnya. 
Pendapat Pejabat DJP dan Pemeriksa Pajak memberikan tanggapan yang berbeda yaitu kriteria pemeriksaan yang sudah disusun dalam sistem pemeriksaan belum dapat diterapkan secara baik karena masih adanya resistensi dari Wajib Pajak dalam proses pemeriksaan. Ditambahkan juga oleh Pemeriksa Pajak bahwa kriteria pemeriksaan saat ini sudah lebih tertata dan terus dilakukan perbaikan secara terus menerus.

Dengan demikian, kriteria pemeriksaan kepada Wajib Pajak merupakan kebijakan dari DJP yang telah disusun dengan suatu sistem, dan semakin banyaknya jumlah Wajib Pajak yang masuk kriteria pemeriksaan merupakan dampak dari resistensi dan tingkat kepatuhan secara material masih diragukan oleh DJP.

\subsection{Standar Pemeriksaan}

Berdasarkan Peratuan Menteri Keuangan Nomor 17/PMK.03/2013, dalam rangka keseragaman, ketertiban dan pertangungjawaban pelaksanaan pemeriksaan secara efektif dan efisien maka pemeriksaan pajak harus memenuhi standar pemeriksaan. Terdapat 3 standar secara umum yang harus dilakukan yaitu standar umum, standar pelaksanaan dan standar pelaporan. Menurut Pejabat DJP menyatakan dalam rangka menjaga kualitas hasil pemeriksaan, DJP sudah menyiapkan peraturan secara rinci yang mengatur tata cara pemeriksaan secara formal dan material yaitu prosedur pemeriksaan, teknik pengujian dan pembuktian. Namun proses pemeriksaan juga tidak lepas dari seni dan kreativitas pemeriksa pajak sehingga kualitas pemeriksaan juga dipengaruhi oleh siapa pemeriksa serta bagaimana implementasi dari metode dan teknik pemeriksaan dikembangkan dalam proses pemeriksaan. Pendapat ini sejalan dengan Pemeriksa Pajak yang menyatakan bahwa kualitas pemeriksaan ditentukan oleh faktor sumber daya manusia dan lingkungan, sehingga adanya standar pemeriksaan yang baik tidak bisa menjamin kualitas pemeriksaan akan baik karena proses pemeriksaan sangat dinamis dan standar pemeriksaan hanya sebagian kecil yang menjadi pedoman proses pemeriksaan. Pendapat ini didukung juga oleh praktisi perpajakan terkait kualitas peraturan pemeriksaan sudah bagus namun belum dilaksanakan secara benar.

Dari sudut pandang Widyaiswara, kualitas pemeriksaan pajak ditentukan dengan menguatkan penyusunan audit plan, agar temuan kecurangan yang dilakukan Wajib Pajak dapat dideteksi secara mendalam dan tidak mudah dibantah oleh Wajib Pajak.

Kualitas pemeriksaan menurut akademisi menyatakan kualitas pemeriksaan ditentukan dari hasil putusan upaya hukum, apabila hasil pemeriksaan dapat disanggah secara formal atau material sehingga mengakibatkan permohonan wajib pajak dikabulkan maka pemeriksaan tersebut tidak kualitas atau tidak bagus.

DJP sudah menetapkan standar pemeriksaan yang mengatur capaian minimum yang dilakukan dalam pemeriksaan. Namun kualitas pemeriksaan lebih banyak dipengaruhi oleh kompetensi pemeriksa pajak dan kedalaman dalam melakukan pengujian atas pos-pos SPT. Hasil pemeriksaan juga akan diuji secara formal dan material di pengadilan pajak apabila Wajib Pajak menempuh upaya hukum.

\subsection{Sengketa Pajak/upaya hukum}

Tindak lanjut hasil pemeriksaan dapat berupa laporan sumir atau laporan hasil pemeriksaan yang menjadi dasar penerbitan surat ketetapan pajak. Apabila menurut Wajib Pajak dalam surat ketetapan pajak terdapat perhitungan pajak yang tidak benar maka dapat diajukan upaya hukum berupa permohonan keberatan dan apabila belum sesuai dapat dilanjutkan permohonan banding atas keputusan keberatan.

Pejabat DJP menyatakan Wajib Pajak tidak setuju atas hasil pemeriksaan disebabkan dasar temuan yang tidak memadai atau Wajib Pajak mempunyai tujuan lain karena dimungkinkan oleh regulasi. Pendapat ini disepakati oleh Pemeriksa Pajak, umumnya perilaku Wajib Pajak akan menyatakan tidak setuju atas setiap hasil pemeriksaan yang berbeda dengan perhitungan pajak yang dilaporkan di SPT. Alasan lainnya Wajib Pajak tidak setuju karena adanya materi temuan yang disebabkan perbedaan interpretasi peraturan perpajakan.

Pendapatan Widyaiswara atas kondisi ini adalah Wajib Pajak memilih tidak setuju atas hasil pemeriksaan lebih banyak disebabkan ketidakmampuan Wajib Pajak untuk melunasi jumlah pajak yang ditetapkan atau menurut Wajib Pajak mengetahui bahwa temuan pemeriksa pajak tidak didukung alat bukti yang kuat.

Pendapat akademisi sejalan dengan Widyaiswara bahwa sebagian hasil pemeriksaan tidak berdasarkan bukti yang menyakinkan dan Wajib Pajak merasa tidak harus membayarnya. Pendapat Praktisi Perpajakan bahwa Wajib Pajak tidak setuju dengan hasil pemeriksaan merupakan hak sehingga tidak perlu dipermasalahkan dan apabila pemeriksa dapat mempertahankan temuannya dengan bukti yang kuat maka Wajib Pajak harus membayar sanksi denda sebesar $50 \%$ sampai dengan $100 \%$ dari jumlah pajak sesuai surat keberatan setelah dikurangi dengan pajak yang telah dibayar sebelum mengajukan keberatan. Hal lainnya yang menyebabkan Wajib Pajak menolak hasil pemeriksaan karena temuan pemeriksaan Menanggapi hasil pemeriksaan Wajib Pajak menyatakan tidak setuju apabila terdapat temuan yang tidak obyektif, koreksi tidak sesuai substance over form atau dasar hukum koreksi tidak kuat. 


\subsection{Bukti Kompeten yang cukup}

Pemeriksaan merupakan serangkaian kegiatan untuk menghimpun dan mengolah data, keterangan dan atau/bukti secara obyektif dan profesional berdasarkan standar pemeriksaan. Standar pemeriksaan mengharuskan bahwa temuan pemeriksaan harus didasarkan pada bukti kompeten yang cukup. Kendala pembuktian temuan sebagai hasil pemeriksaan menurut pendapat pejabat DJP sulit diwujudkan karena resistensi Wajib Pajak sehingga data dan informasi yang digunakan dalam penetapan pajak sangat terbatas. Selain itu kualitas pemeriksaan ditentukan oleh kemampuan pemeriksa pajak dalam mengidentifikasi tax gap antara data, keterangan atau bukti yang ditemukan dalam pemeriksaan untuk nantinya akan dilakukan pengujian berdasarkan teknik pemeriksaan. Hasil pengujian ini dikaitkan pembuktian dan dasar hukum yang berlaku. Menurut Pemeriksa Pajak, kualitas pemeriksaan ditentukan oleh sejauhmana pemeriksa pajak dapat melaksanakan prosedur pemeriksaan sebagaimana telah ditetapkan pada Peraturan Menteri Keuangan yaitu 17/PMK.03/2013 serta perubahannya Peraturan Menteri Keuangan 184/PMK.03/2015.

Kualitas Pemeriksaan menurut Widyaiswara ditunjukkan apabila pemeriksaan dilaksanakan berdasarkan standar pemeriksaan dan pembuktian temuan yang didukung bukti yang kuat. Pendapat ini didukung oleh pihak akademisi bahwa kualitas pemeriksaan hanya ditentukan berdasarkan kuat tidaknya pembuktian di pengadilan pajak. Hasil pemeriksaan dinyatakan berkualitas apabila menang di pengadilan pajak dan sebaliknya. Kualitas pemeriksaan menurut praktisi ditunjukkan dari obyektivitas pemeriksa dalam menyajikan temuan pemeriksaan, artinya temuan yang obyektif dan tidak multi tafsir akan menentukan kualitas dari hasil pemeriksaan.

Dengan demikian, upaya hukum yang dilakukan Wajib Pajak pada dasarnya disebabkan adanya keraguan atas dasar temuan yang digunakan pemeriksa pajak untuk penghitung pajak terhutang sehingga diharapkan hasil pemeriksaan dapat ditetapkan secara obyektif dan tidak multi tafsir.

\section{KESIMPULAN DAN SARAN}

Berdasarkan analisis dan pembahasan, penulis menarik beberapa kesimpulan sebagai berikut :

1. Wajib Pajak tidak setuju dengan hasil pemeriksaan dan mengajukan upaya hukum tidak berkaitan dengan kualitas hasil pemeriksaan tetapi disebabkan faktor lain seperti adanya perbedaan persepsi mengenai penerapan peraturan perpajakan atau ketidakmampuan Wajib pajak membayar Surat Ketetapan Pajak.
2. Upaya hukum yang dilakukan Wajib Pajak sebagian besar menang di Pengadilan Pajak disebabkan lemahnya bukti pemeriksaan secara formal maupun material. Bukti formal tentunya pemeriksa harus memenuhi setiap tahapan pemeriksaan yang sudah ditetapkan mulai dari penyusunan audit plan sampai dengan pembahasan akhir hasil pemeriksaan. Bukti Material berkaitan dengan cara pemeriksa pajak menghimpun bukti pemeriksaan yang kompeten yang cukup dan dapat dijadikan alat bukti di Pengadilan Pajak.

\section{IMPLIKASI DAN} KETERBATASAN

1. Sumber pembahasan diperoleh hanya berasal dari wawancara narasumber dan studi literatur. Peneliti tidak melakukan observasi secara langsung proses pemeriksaan pajak;

2. Karena keterbatasan waktu, pembahasan kualitas hanya dilakukan pada Kantor Pusat Direktorat Jenderal Pajak (KPDJP).

\section{DAFTAR PUSTAKA}

Asmorowati, Meiti, (2011), Sengketa Keberatan Dibandingkan dengan Sengketa Pengadilan Pajak berdasarkan Peraturan yang berlaku. Bandung; Jurnal wawasan Yuridika, Sekolah Tinggi Hukum Bandung.

Bungin H.M. Burhan, (2011), Penelitian Kualitatif, Edisi kedua. Jakarta: Prenada Media Group

BWoga, Hanantha, (2006), Pemeriksaan Pajak Yang (hampir selalu) menimbulkan kontroversi. Jakarta: Universitas Trisakti

Elim, Inggriani; Panga, Ricky Billy, (2015). Analisis Efektifitas Pemeriksaan Pajak dalam Upaya Meningkatkan Penerimaan Pajak pada Kantor Pelayanan Pajak Pratama Bitung. Universitas Sam Ratulangi

Gunadi (2016). Ketentuan Umum Perpajakan. Jakarta: Bee Media Indonesia.

Gunadi, (2004). Bunga Rampai Pemeriksaan Penyidikandan Penagihan Pajak. Jakarta: MUC Publishing

Gunarso, Pujo, (2016). Pemeriksaan Pajak dan Sanksi Pajak Terhadap Kepatuhan Wajib Pajak badan Pada KPP Kepajen Kabupaten Malang, Malang; Universitas Merdeka Malang.

Hidayat, Rudy; Cheisviyanny, Charoline, (2013). Pengaruh Kualitas Penetapan Pajak dan Tindakan Penagihan Aktif terhadap Pencairan Tunggakan Pajak. Padang: Wahana Riset Akuntansi UNP.

Kurniawan, Anang Mury, (2011). Upaya Hukum Terkait dengan Pemeriksaan, Penyidikan dan Penagihan Pajak. Yogyakarta: Graha Ilmu.

Nurlaila, Siti (2017). Pengaruh Kualitas Penetapan Pajak dan Tindakan Penagihan Aktif terhadap Pencairan Tunggakan Pajak (studi kasus KPP 
Pratama Tangerang Timur). Banten Universitas Pamulang.

Pohan, Chairil Anwar (2017). Pengantar Perpajakan. Jakarta: Mitra Wacana Media.

Sugiyono. (2016). Metode Penelitian Kuantitatif, Kualitatif, dan R\&D. Bandung: Alfabeta, CV.

Siti Kurnia Rahayu, (2009), Perpajakan Indonesia, Yogyakarta: Graha IImu.

Sunhaji, Ahmad, (2013). Pengaruh Kompetensi dan Etika Pemeriksa Pajak terhadap Kualitas Pemeriksaan Pajak, Yogyakarta: Universitas Gajah Mada

Undang-Undang Ketentuan Umum dan Tata Cara Perpajakan. Undang-Undang No.6/1983 tentang Ketentuan Umum dan Tata Cara Perpajakan sebagaimana telah beberapa kali diubah terakhir dengan Undang-Undang No. 16/2009

Kementerian Keuangan Republik Indonesia. (2013) Peraturan Menteri Keuangan Nomor 17/PMK.03/2013 tentang Tata Cara Pemeriksaan. Jakarta; Kementerian Keuangan Republik Indonesia

Kementerian Keuangan Republik Indonesia. (2013) Peraturan Menteri Keuangan Nomor 184/PMK.03/2015 tentang perubahan atas Peraturan Menteri Keuangan Nomor 17/PMK.03/2013 tentang Tata Cara Pemeriksaan. Jakarta; Kementerian Keuangan Republik Indonesia

Direktorat Jenderal Pajak (2013). Peraturan Direktur Jenderal Pajak Nomor PER-23/PJ/2013 tentang Standar Pemeriksaan. Jakarta: Direktorat Jenderal Pajak.

Direktorat Jenderal Pajak (2010). Surat Edaran Direktur Jenderal Pajak Nomor SE-126/PJ/2010 tentang Pedoman Penyusunan Rencana Pemeriksaan (Audit Plan) Untuk menguji
Kepatuhan Pemenuhan Kewajibab Perpajakan. Jakarta: Direktorat Jenderal Pajak.

Direktorat Jenderal Pajak (2012). Surat Edaran Direktur Jenderal Pajak Nomor SE-04/PJ/2012 tentang edoman Penyusunan Program Pemeriksaan Untuk menguji Kepatuhan Pemenuhan Kewajibab Perpajakan. Jakarta: Direktorat Jenderal Pajak.

Direktorat Jenderal Pajak (2012). Surat Edaran Direktur Jenderal Pajak Nomor SE-08/PJ/2012 tentang Pedoman Penyusunan Program Pemeriksaan Untuk menguji Kepatuhan Pemenuhan Kewajibab Perpajakan. Jakarta: Direktorat Jenderal Pajak.

Direktorat Jenderal Pajak (2013). Surat Edaran Direktur Jenderal Pajak Nomor SE-65/PJ/2013 tentang Pedoman Penggunaan Metode dan Teknik Pemeriksaan. Jakarta: Direktorat Jenderal Pajak.

Direktorat Jenderal Pajak (2015). Surat Edaran Direktur Jenderal Pajak Nomor SE-24/PJ/2015 tentang Pedoman Penyusunan Laporan Hasil Pemeriksaan. Jakarta: Direktorat Jenderal Pajak.

Direktorat Jenderal Pajak (2016). Surat Edaran Direktur Jenderal Pajak Nomor SE-06/PJ/2016 tentang Kebijakan Pemeriksaan. Jakarta: Direktorat Jenderal Pajak.

Direktorat Jenderal Pajak (2017). Surat Edaran Direktur Jenderal Pajak Nomor SE-10/PJ/2017 tentang Petunjuk Teknis Pemeriksaan Lapangan Dalam Rangka Pemeriksaan Untuk Menguji Kepatuhan Pemenuhan Kewajiban Perpajakan. Jakarta: Direktorat Jenderal Pajak, 2017.

Direktorat Jenderal Pajak (2017). Surat Edaran Direktur Jenderal Pajak Nomor SE-11/PJ/2017 tentang Rencana, Strategi, dan Pengukuran Kinerja Pemeriksaan Tahun 2017. Jakarta: Direktorat Jenderal Pajak. 